\title{
ANALISIS KANDUNGAN ASPARTAM YANG TERDAPAT PADA MINUMAN JAJANAN ANAK SEKOLAH YANG BEREDAR DI MAKASSAR DENGAN METODE HPLC
}

\author{
Seniwati Dali ${ }^{*}$, A.Trihadi Kusuma ${ }^{\star *}$, Afiat Wahyuni Anar ${ }^{\star *}$ \\ *) Jurusan Kimia Fakultas MIPA Universitas Hasanuddin \\ ${ }^{* *}$ Fakultas Farmasi Universitas Muslim Indonesia \\ Email : makassar_91@ymail.com
}

\begin{abstract}
This research have done of Aspartame compound in seven kinds of beverage of the student which turn in elementary school with tehe mean that to analyze Aspartame compound in beverage and have purpose to determine the concentration of Aspartame in beverage. As a comparison used the main of Aspartame with purity about $98,38 \%$. The sample is weigh about $10 \mathrm{gram}$ in a flask $50 \mathrm{ml}$, and then diluted with mobile phase is sodium dihydrogen phosphate and acetonitrile $(82.5: 17.5) \mathrm{ml}$ and then it's filtered by membrane filter 0,45 um. The result are sonicated and to injection about $20 \mathrm{ml}$ to in colomn with rate of flow $1,2 \mathrm{mk} / \mathrm{min}$ and $\lambda 210 \mathrm{~nm}$. The sample is analyzed by HPLC method. The analyzed showed that the average concentration of Aspartame by calculating linear regression equation contained in the sample A. $7.5658 \mathrm{mg} / \mathrm{kg}$, B. $198.3445 \mathrm{mg} / \mathrm{kg}$, C. $257.8844 \mathrm{mg} / \mathrm{kg}$, D. 226.5515 $\mathrm{mg} / \mathrm{kg}$, E. $0 \mathrm{mg} / \mathrm{kg}, F .45 .5389 \mathrm{mg} / \mathrm{kg}, \mathrm{G} .140 .3748 \mathrm{mg} / \mathrm{kg}$ which is still below the standard of $600 \mathrm{mg} / \mathrm{kg}$. So, sample E is just not contain of Aspartame.
\end{abstract}

Key words : Aspartame, HPLC, Compound, Analyze

\section{PENDAHULUAN}

Seiring dengan meningkatnya pertumbuhan industri makanan dan minuman di Indonesia, khususnya telah terjadipeningkatan produksi minuman yang beredar luas di masyarakat. Pada minuman tersebut sering ditambahkan bahan alami maupun bahan tambahan, tetapi akhirakhir ini sering didapatkan bahan tambahan pada produksi minuman seperti pemanis buatan yang kadarnya perlu diperhatikan, karena apabila konsumsinya berlebihan dapat membahayakan kesehatan (Soerjodibroto, 2002).

Makassar merupakan salah satu kota tempat produksi minuman dimana produknya banyak beredar di pasaran dan telah di konsumsi banyak masyarakat khusunya anak-anak. Produksi minuman tersebut biasanya diolah di pabrik yang ditangani oleh ahli dan pengawasan khusus dan ada 
Analisis Kandungan Aspartam Yang Terdapat Pada Minuman Jajanan Anak Sekolah Yang Beredar Di Makassar Dengan Metode HPLC

pula sebaliknya yang diolah sendiri di rumah tanpa ahli dan pengawasan. Dalam mengolah produk minuman tersebut seringkali ditambahkan pemanis buatan yang berbahaya. Tetapi masyarakat tidak mengetahui kandungan pemanis buatan apakah yang ditambahkan ke dalam produk minuman tersebut dan kadarnya apakah sudah tepat atau berlebih berdasarkanaturan yang telah ditetapkan oleh Menteri Kesehatan.

Salah satu sarana atau tempat distribusinya suatu minuman tersebut adalah sekolah dan lebih tepatnya sekolah dasar (SD). Dimana anakanak menjadi sasaran utama dalam penjualan minuman tersebut karena mereka tidak atau belum mengetahui kandungan apa saja yang ditambahkan dalam minumannya. Apalagi minuman yang dijual tersebut memiliki warna yang mencolok sehingga menjadi daya tarik bagi anak-anak. Oleh sebab itu minuman yang dimaksud dalam penelitian ini adalah minuman jajanan anak sekolah.

Analisis bahan tambahan di dalam minuman pada penelitian ini menggunakan metode HPLC (High Performance Liquid Chromatography) atau Kromatografi Cair Kinerja Tinggi (KCKT), karena analisis dengan KCKT cepat, daya pisah baik, peka, penyiapan sampel mudah, dan dapat dihubungkan dengan detektor yang sesuai (Johnson, 1991). Beberapa pustaka menunjukkan bahwa metode KCKT fase terbalik merupakan metode terpilih untuk analisis campuran bahan tambahan tersebut, karena zat-zat tersebut bersifat polar dan larut dalam air sehingga sulit dipisahkan menggunakan KCKT fase normal yang menggunakan kolom polar dan fase gerak yang bersifat non polar (Meyers, 2000; Nollet, 1996).

\section{METODE PENELITIAN}

\section{Penyiapan Sampel}

Proses sampling minuman dilakukan berdasarkan yang beredar di Makassar. Tujuh minuman dipilih untuk dijadikan sampel dalam penelitian ini. Pemilihan sampel berdasarkan secara acak yang banyak di konsumsi anak-anak dan beredar di sekolah-sekolah.

\section{Pembuatan larutan baku}

Sejumlah lebih kurang $25 \mathrm{mg}$ aspartame baku, ditimbang seksama dimasukkan kedalam labu tentukur 50 $\mathrm{ml}$, ditambah $25 \mathrm{ml}$ fase gerak, dikocok sampai larut dan diencerkan dengan fase gerak sampai tanda, $\operatorname{kocok}(A)$. 
Analisis Kandungan Aspartam Yang Terdapat Pada Minuman Jajanan Anak Sekolah Yang Beredar Di Makassar Dengan Metode HPLC

Pembuatan Larutan Uji

Sejumlah lebih kurang 10 gram cuplikan ditimbang seksama, dimasukkan ke dalam labu tentukur 50 $\mathrm{ml}$ ditambah $25 \mathrm{ml}$ fase gerak, dikocok kemudian ditambah fase gerak hingga tanda, dikocok dan disaring dengan penyaring membran $0,45 \mu \mathrm{m}$ dan di awaudarakan (sonikasi).

\section{Penetapan kadar}

Larutan A dan B masing-masing diinjeksikan secara terpisah dan dilakukan kromatografi cair kinerja tinggi dengan kondisi sebagai berikut : Fase diam : Oktadesilsilan dengan partikel 5 $\mu \mathrm{m}, 250 \times 4,6 \mathrm{~cm}$ atau kolom lain yang setara

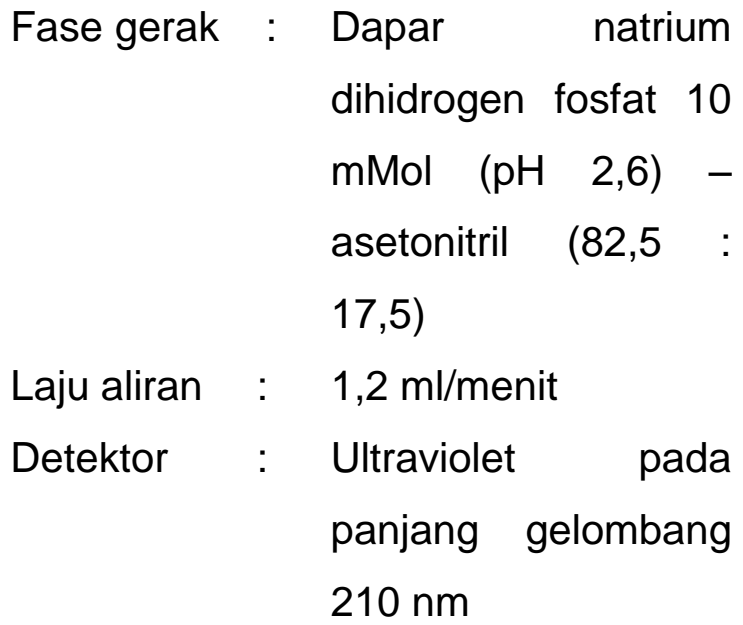

Volume penyuntikkan : $20 \mu \mathrm{L}$

\section{HASIL PENELITIAN}

Hasil penelitian tentang analisis kandungan aspartam yang terdapat pada minuman jajanan anak sekolah yang beredar di Makassar dengan metode HPLC dapat dilihat pada tabel berikut ini :

Tabel 1. Tabel hasil kromatogram menggunakan metode HPLC

Bahan Baku Aspartam A-G dengan

\begin{tabular}{cccl}
\hline Baku Seri & Retention Time & Luas Area & Name \\
\hline $5 \mathrm{mg} / \mathrm{kg}$ & 6.240 & 82238 & Aspartam \\
$10 \mathrm{mg} / \mathrm{kg}$ & 6.266 & 166649 & Aspartam \\
$20 \mathrm{mg} / \mathrm{kg}$ & 6.282 & 333128 & Aspartam \\
$30 \mathrm{mg} / \mathrm{kg}$ & 6.297 & 499688 & Aspartam \\
$40 \mathrm{mg} / \mathrm{kg}$ & 6.130 & 663110 & Aspartam \\
$50 \mathrm{mg} / \mathrm{kg}$ & 6.312 & 825784 & Aspartam \\
$61 \mathrm{mg} / \mathrm{kg}$ & 6.313 & 1053614 & Aspartam \\
\hline
\end{tabular}


Analisis Kandungan Aspartam Yang Terdapat Pada Minuman Jajanan Anak Sekolah Yang Beredar Di Makassar Dengan Metode HPLC

Tabel 2. Tabel hasil kromatogram Sampel Minuman Jajanan Anak Sekolah A-G dengan menggunakan metode HPLC.

\begin{tabular}{cccc}
\hline Sampel & Time & Area & Name \\
\hline $\mathrm{A}_{1}$ & 6.158 & 14679 & Aspartam \\
$\mathrm{A}_{2}$ & 6.162 & 13979 & Aspartam \\
$\mathrm{B}_{1}$ & 6.389 & 594960 & Aspartam \\
$\mathrm{B}_{2}$ & 6.386 & 679129 & Aspartam \\
$\mathrm{C}_{1}$ & 6.478 & 755877 & Aspartam \\
$\mathrm{C}_{2}$ & 6.475 & 867674 & Aspartam \\
$\mathrm{D}_{1}$ & 6.388 & 589052 & Aspartam \\
$\mathrm{D}_{2}$ & 6.380 & 756476 & Aspartam \\
$\mathrm{E}_{1}$ & - & - & - \\
$\mathrm{E}_{2}$ & 6.329 & 144780 & Aspartam \\
$\mathrm{F}_{1}$ & 6.351 & 142823 & Aspartam \\
$\mathrm{F}_{2}$ & 6.348 & 431350 & Aspartam \\
$\mathrm{G}_{1}$ & 6.333 & 466911 & Aspartam \\
$\mathrm{G}_{2}$ & & &
\end{tabular}

Tabel 3. Tabel analisis kadar Aspartam pada minuman jajanan anak sekolah A-G dengan menggunakan metode HPLC.

\begin{tabular}{clc}
\hline No & \multicolumn{1}{c}{ Sampel } & Kadar $\boldsymbol{m g} / \boldsymbol{k g}$ \\
\hline 1. & A (Orange) & 7,5658 \\
2. & B (Hijau) & 198,3445 \\
3. & C (Hitam) & 258,0820 \\
4. & D (Bening) & 226,5515 \\
5. & E (Coklatmuda) & - \\
6. & F (Birumuda) & 45,5389 \\
7. & G (Kuning) & 140,3748 \\
\hline
\end{tabular}

\section{PEMBAHASAN}

Penelitian ini dilakukan dengan menganalisis kandungan pemanis buatan "Aspartam" yang terdapat pada minuman yang beredar di Makassar dengan metoode HPLC. Penelitian ini bertujuan untuk menentukan kandungan dan kadar pemanis buatan "Aspartam" dan menetapkan kadar tersebut sesuai yang diterapkan Menteri Kesehatan. Minuman yang dimaksud disini termasuk dalam kategori PJAS (Pangan Jajanan Anak Sekolah) artinya minuman yang beredar di sekolah-sekolah, dalam hal ini yang dimaksud adalah sekolah dasar (SD). Minuman tersebut lebih dikhususkan pada minuman olahan rumah tangga atau yang diproduksi di rumah.

$\begin{array}{ccc}\text { Pada } & \text { umumnya } & \text { dalam } \\ \text { pembuatan } & \text { minuman } & \text { tidak } \\ \text { sepenuhnya } & \text { menggunakan } & \text { gula }\end{array}$
sebagai bahan pemanisnya, melainkan sebagian menggunakan pemanis buatan seperti Aspartam. Hal tersebut bertujuan untuk mencari keuntungan, karena di samping harganya relatif lebih murah juga mempunyai tingkat kemanisan yang 
Analisis Kandungan Aspartam Yang Terdapat Pada Minuman Jajanan Anak Sekolah Yang Beredar Di Makassar Dengan Metode HPLC

jauh lebih tinggi dari pemanis alami seperti sukrosa.

Teknik pengambilan sampel dilakukan secara acak sehingga diperoleh sampel sebanyak 7 (A, B, C, $D, E, F, G)$ jenis minuman. Secara organoleptik sampel tersebut memiliki jenis warna yang berbeda sehingga dapat mewakili dari setiap lokasi atau tempat pengambilan sampel.

Aspartam merupakan pemanis sintetis yang dikenal dengan nama dagang equal dan nama kimia aspartil fenilalanin merupakan pemanis yangdigunakan dalam produk-produk minuman ringan. Aspartam termasuk pemanis rendah kalori dan pengggunaannya sudah disetujui tetapi tetap harus memperhatikan kadar yang terkandung dalam suatu minuman. Minuman jajanan anak sekolah sampel $A, B, C, D, F$, dan $G$ mengandung pemanis buatan yaitu Aspartam. Kandungan tersebut masih dalam range dan berada di bawah batas maksimum yang ditetapkan yaitu $600 \mathrm{mg} / \mathrm{kg}$ BB. Hanya sampel E yang tidak mengandung Aspartam.

Sampel yang akan di analisis terlebih dahulu ditimbang sebanyak 10 gram kemudian dimasukkan ke dalam labu ukur $50 \mathrm{ml}$ dan ditambahkan 25 $\mathrm{ml}$ fase gerak lalu dikocok, ditambahkan lagi fase gerak sampai batas tanda. Kemudian disaring dengan penyaring membran $0,45 \mu \mathrm{m}$ yang bertujuan agar larutan uji yang ingin dianalisis sudah jernih dan tidak mengandung zat pengotor lagi. Setelah itu dilakukan sonifikasi untuk menghomogenkan kembali larutan uji sehingga siap untuk di injeksikan ke dalam HPLC.

Selain larutan uji, disiapkan pula larutan baku sebagai pembanding dengan sampel minuman dimana ditimbang $25 \mathrm{mg}$ baku induk aspartam dimasukkan dalam labu ukur $50 \mathrm{ml}$, lalu ditambahkan $25 \mathrm{ml}$ fase gerak dan dikocok sampai larut. Kembali diencerkan dengan fase gerak sampai batas tanda (larutan baku induk). Setelah itu, dipipet 0,$5 ; 1,0 ; 2,0 ; 3,0$; 4,$0 ; 5,0 ; 6,0$ dan dimasukkan dalam labu ukur $50 \mathrm{ml}$, ditambahkan fase gerak sampai batas tanda dan dikocok. Kemudian disaring dengan penyaring membran $0,45 \mu \mathrm{m}$ dan disonikasi \pm 5 menit (larutan baku seri).

Larutan baku dan larutan uji menggunakan fase gerak yang sama yaitu dapar natrium dihidrogen fosfat $(\mathrm{pH} \mathrm{2,6)}$ dan asetonitril $(82,5: 17,5)$. Kedua larutan tersebut siap untuk di analisis, dimana HPLC dijalankan dengan laju alir $1,2 \mathrm{ml} / /$ menit, detektor uv dengan $\lambda=210 \mathrm{~nm}$. 
Analisis Kandungan Aspartam Yang Terdapat Pada Minuman Jajanan Anak Sekolah Yang Beredar Di Makassar Dengan Metode HPLC
Ditjen POM,1995, Farmakope Indonesia, edisi keempat, Departemen Kesehatan RI, Jakarta.

Gritter, Roy, 1991, Pengantar Kromatografi, terbitan ke dua, ITB, Bandung.

Hasan, Mustafa, 2000, Teknik Sampling, Jakarta, Erlangga.

Indrie, Ambarsari dan Qanytah, 2007, Penerapan Standar Penggunaan Pemanis Buatan Pada Produk Pangan, Balai Pengkajian Teknologi Pertania, Sidomulyo, Jawa Tengah.

Johnson, E.L., Robert Stevenson, 1991, Dasar Kromatografi Cair, Terjemahan Dari Basic Liquid Chromatography, oleh Padmawinata, Institut Teknologi bandung, Bandung.

Khopkar, 2003, Konsep Dasar Kimia Analitik, Penerbit Universitas Indonesia, Jakarta

Kibbe, A.H., (2000), Handbook of Pharmaceutical Excipients ${ }^{3 t h}$, American Pharmaceutical Press, Washington DC.

Meyer, V. R. (2004). Practical HighPerformance Liquid Chromatography. 4th Edition. St. Gallen: John Wiley \& Sons. Ltd. Hal 20-24, 52-55.

Meyers, RA. Encyclopedia of analytical chemistry, vol 5, New York :John Wiley and Sons Ltd, 2000 :4066-4067.

Meyers, RA. Enclyclopedia of analytical chemistry, vol 13, New York :John Wiley and Sons Ltd, $2000: 11428-11450$.
Mulja, M., dan Suharman, 1995, Analisis Instrumental, Airlangga University Press, Surabaya.

Nollet, Leo. Handbook of food analysis, vol 2, New York : Marcell Dekker Inc, 1996 : 1745-1746,1835-1844, 18531857.

Rohman, A,2007,Kimia Farmasi Analisis. Cetakan I, Pustaka Pelajar. Yogyakarta, Hal. 467.

Sastroamidjojo. S, 2001.,ObatAsl Indonesia, Cetakan Keenam, Penerbit Dian Rakyat, Jakarta.

Sekaran, Uma. 1992. Research Methods For Business: A Skill Building Approach, Secon Edition, John Willey \&Sons, Inc. New York.

Soerjodibroto, Waluyo, 2002. Menyimak kandungan soft drink, 26 Februari: $1 \mathrm{hlm}$. http://www.kompas.com/health/ news/0202/26051556 html, 5 Oktober 2012, pk. 21.00.

SNI 01-6993-2004,Bahan Tambahan Pangan Pemanis Buatan Persyaratan Penggunaan Dalam Produk Pangan, Badan Standardisasi Nasional.

Usmiati, S., danYuliani, S., 2004,Pemanis Alami dan Buatan untuk Kesehatan, Warta Penelitian dan Pengembangan Tanaman Industri 10.

Winarno, F.G., 1992, Kimia Pangan dan Gizi, Penerbit PT. Gramedia, Jakarta.

Winarti, S., 2006, Minuman Kesehatan,Trubus Agrisarana, Surabaya. 